ГУМАНІТАРИЗАЦІЯ ОСВІТИ ЯК ПЕДАГОГІЧНА УМОВА ЕФЕКТИВНОСТІ РЕАЛІЗАЦІЇ ПРОФЕСІЙНОГО САМОВИЗНАЧЕННЯ МАЙБУТНІХ УЧИТЕЛІВ ХІМІї

\title{
THE HUMANITARIZATION OF EDUCATION AS A PEDAGOGICAL REQUIREMENT OF THE EFFECTIVE REALIZATION OF PROFESSIONAL SELF-DETERMINATION OF FUTURE CHEMISTRY TEACHER
}

Статтю присвячено дослідженню педагогічних умов забезпечення професійного самовизначення майбутніх учителів хімії, а саме розкриттю гуманітаризації освіти як умови формування педагогічної готовності майбутніх учителів хімії до реалізації професійного самовизначення. У статті визначено поняття «профресійне самовизначення майбутніх учителів хімії» як чілеспрямований процес вступу особистості в сореру майбутньої профресійної діяльності. Здійснено теоретичний аналіз поняття «гуманітаризація» як педагогічної умови ефективності реалізації професійного самовизначення майбутніх учителів хімії. Розглядається мета гуманітаризації професійної підготовки майбутніх учителів хімії, виокремлюються основні напрями гуманітаризації освітнього процесу в педагогічних закладах вищої освіти. Доведено необхідність гуманітаризації освіти в сучасних умовах розвитку суспільства, що сприяє формуванню готовності майбутніх учителів хімії до професійного самовизначення. Окреслено шляхи гуманітарного викладання фрахових дисциплін у педагогічних закладах вищої освіти.

У своєму дослідженні автор прагне розкрити рівень дидактичного синтезу хімічних, природничих, психолого-педагогічних і методичних дисциплін. Інтегруючим фрактором $\epsilon$ проблема, пов'язана з розвитком у студентів уміння вирішувати навчально-профресійні задачі в процесі формування професійного самовизначення майбутнього вчителя хімії. Розкрито поняття навчального наративу як дидактичної категорії та показано значення навчального наративу в процесі гуманітаризації освіти майбутніх учителів хімії. Встановлено, що гуманітаризація освітнього процесу під час підготовки учителів хімії в педагогічних закладах вищої освіти $\epsilon$ необхідною складовою частиною освітнього процесу $і$ важливою умовою фрормування готовності майбутніх учителів-хіміків до реалізації професійного самовизначення. Гуманітаризація дасть змогу підготувати висококваліфрікованого і всебічно розвиненого учителя хімії, здатного до саморозвитку і самоосвіти, фрахівця з високою мотиваційною готовністю до профресійнотворчої діяльності.

Ключові слова: профресійне самовизначення, організаційно-педагогічні умови, гуманітаризація освіти, освітній процес навчальний наратив.

Modern Ukrainian school needs a teacher who is able to realize himself within teacher profession, take the responsibility for solving important tasks, the one who is creative, capable for selfdevelopment and self-realization. To identify pedagogical conditions of providing professional self-determination of future Chemistry teachers, including depicting the humanitarization of edu cation as a requirement of forming pedagogical readiness of future Chemistry teacher to realize professional self-determination. The notion "professional self-determination of future Chemistry teacher" was defied as a purposeful process of the individual entering the sphere of future professional activity. The theoretical analysis of the notion "Humanitarization" was made as a pedagogical condition of effective realization of professional self-determination of future Chemistry teacher. The aim of humanitarization of professional preparation of future Chemistry teachers, the main branches of humanitarization of educational process in pedagogical establishments of higher education are allocated. The necessity of humanitarization of education in the curren conditions of the development of the society was proved; it assists the forming of readiness of future Chemistry teachers to professional self-determination. The ways of humanitarian teaching of specializing disciplines in pedagogical establishments of higher education were outlined. The notion "narrative" as a didactic category was depicted and the meaning of studying narrative in the process of humanitarization of the education of future Chemistry teacher was demonstrated. Humanitarization of the educational process while preparing Chemistry teachers in the pedagogical establishments of higher education is a necessary part of educational process and an important element of forming the readiness of future Chemistry teachers to realize professional selfdetermination. Humanitarization will help to prepare highly-qualified and generally-educated Chemistry teacher who tends to self-development and self-education, a specialist with high motivated readiness to professional activity. Key words: professional self-determination, pedagogical environment, humanitarization of education, educational process, educational narrative.
Постановка проблеми у загальному вигляді. Сучасна українська школа потребує вчителя, здатного реалізувати себе у педагогічній професії, приймати на себе відповідальність за вирішення важливих завдань, розсовувати рамки професійної діяльності, креативного, здатного до саморозвитку та самореалізації.

Тому педагогічні заклади вищої освіти мають надати майбутнім педагогам всебічну фрахову під- готовку, забезпечити високий педагогічний рівень їх навчання і виховання, сприяти їм у профресійному самовизначенні, підготувати до успішної професійної діяльності, створити умови для переходу студента в позицію суб'єкта своєї діяльності, іншими словами, самовизначитися.

Таким чином, для реалізації профресійного самовизначення майбутніх учителів, зокрема учителів хімії, необхідне створення низки організа- 
ційно-педагогічних умов, які дадуть змогу ефективно побудувати вказаний процес. Серед таких умов ми окремо виділяємо гуманітаризацію освіти як складову частину гуманізації, яка сприяє фрормуванню професійно-особистісних якостей, свідомості та мислення, розширює духовний потенціал і загальнолюдські цінності.

Аналіз останніх досліджень і публікацій. У психологічній, фрілософській, педагогічній літературі, інформаційних ресурсах поняття «самовизначення» трактується з різних позицій:

- фрілософрської - пошук особистістю сенсу життя й усвідомлення нею своїх можливостей (Л. Архангельський, Н. Зотов, Л. Коган, І. Кон, А. Спіркін, М. Шибаєва та ін.);

- психологічної - визначення особистістю власної стратегії життя (Л. Божович, Є. Клімов, І. Кон, Т. Кудрявцев, А. Мудрик, С. Рубінштейн, В. Сасрін та ін.);

- соціальної - шляхи та способи самовизначення в конкретних соціальних умовах ( $€$. Головаха, В. Журавльова, С. Іконнікова, В. Лісовський, В. Неміровський, М. Руткевич, Л. Сохань та ін.);

- профресійної - процес формування особистістю свого ставлення до професійно-трудової сорери та спосіб ії реалізації (К. АбульхановаСлавська, О. Борисова, Є. Головаха, В. Поляков, М. Пряжнікова, М. Скаткін, С. Чистячкова та ін.);

- сімейної - усвідомлений процес конструювання у часовій перспективі образу сім'ї (С. Мерзлякова, Н. Обознов, А. Харчав та ін.);

- моральної - вільна самодетермінація людиною своїх думок і вчинків ( М. Абдулаєв, В. Горділов, О. Марченко, Г. Омарова, Ю. Руденко та ін.);

- особистісної - процес, спрямований на пошук мети і сенсу свого життя (Н. Будич, Т. Буякас, М. Гінзбург, О. Зєвіна, Т. Канаєва, А. Маркова, Н. Пряжніков, В. Сафрін та ін.);

- релігійної - вибір системи цінностей конкретного віровчення (М. Бабій, Г. Лісовська, Т. Сізікова, А. Тащіян, Л. Філіпович) тощо.

у межах нашого дослідження зупинимося на професійному самовизначенні.

На нашу думку, найбільш повно поняття «професійне самовизначення» розкрито в роботах В. Полякова та С. Чистякової. Автори розглядають профресійне самовизначення як «складний психічний стан особистості, що включає в себе професійне спрямування (коло інтересів, мотивів, потреб, нахилів, ідеалів і установок людини), а також самосвідомість - коли учень виступає суб'єктом діяльності, своє ставлення до дійсності усвідомлює як особистісне» [1, с. 33].

Ми згодні з С. Кіпуровою і Д. Малим, що «професійне самовизначення - складний процес інтеграції молоді в соціально-професійну структуру суспільства, який реалізується на особистісному рівні через ціннісний вибір суб'єктом варіантів свого профресійного розвитку. Виходячи із запропонованого розуміння процесу професійного самовизначення, цей френомен слід розглядати в контексті особистісного розвитку, тому що професійне самовизначення невіддільне від особистісного набуття і реалізації людиною своєї ціннісно-смислової єдності» [2, с. 111].

Проаналізувавши низку сучасних досліджень із зазначеної проблеми, можна стверджувати, що «професійне самовизначення майбутніх педагогів» як наукова дефініція розглядається в двох аспектах: вибір учительської професії та профресійне становлення особистості, яке супроводжує її протягом усього життя і $є$ цілеспрямованим процесом вступу особистості в сореру майбутньої професійної діяльності.

Виділення не вирішених раніше частин загальної проблеми. Незважаючи на те, що такі дослідження зробили вагомий внесок у розробку проблеми професійного самовизначення майбутніх фрахівців, зокрема майбутніх педагогів, питання забезпечення професійного самовизначення майбутніх учителів хімії в процесі фрахової підготовки не було окремою темою дослідження.

Мета статті - виявити педагогічні умови забезпечення професійного самовизначення майбутніх учителів хімії, а саме розкрити гуманітаризацію освіти як умову фрормування педагогічної готовності майбутніх учителів хімії до реалізації просресійного самовизначення.

Виклад основного матеріалу. Проблема фрормування готовності майбутніх учителів хімії до професійного самовизначення передбачає врахування цілої низки організаційно-педагогічних умов, які дадуть змогу ефрективно побудувати процес фрормування такої готовності.

Під організаційно-педагогічними умовами ми розуміємо таку сукупність педагогічних умов, які дадуть змогу забезпечити удосконалення процесу фрормування профресійного самовизначення майбутніх педагогів [3, с. 422]. Серед основних педагогічних умов, що сприяють реалізації професійного самовизначення майбутніх учителів хімії, ми виділяємо такі як:

- всебічна гуманітаризація хімічної освіти;

- проходження педагогічної практики;

- фрормування ІКТ-компетентності;

- реалізація науково-дослідної діяльності;

- застосування інноваційних методів навчання.

На нашу думку, однією 3 найважливіших умов готовності майбутніх учителів хімії до реалізації професійного самовизначення є гуманітаризація освіти.

В Енциклопедії освіти зазначено, що гуманітаризація освіти - це процес переорієнтації освіти 3 предметно-змістового принципу навчання основ наук на вивчення цілісної картини світу, пов'язаний 3 посиленням впливу гуманітарних наук на всі 
види пізнання; переміщення акцентів 3 «природи і суспільства» на «людину в природі і суспільстві», звернення уваги на самоцінність особи. Гуманітаризація освіти передбачає також синтез гуманітарних, природничих та технічних знань, їх органічне поєднання, що $є$ основою формування цілісної картини світу, ефрективне використання гуманітарного потенціалу предметів природничо-математичного циклу [4, с. 157].

Як зазначають К. Чермит і В. Левченко, «нині $€$ реальна можливість дати людині оволодіти не лише базовими професійними знаннями, але i загальнолюдською культурою, на основі якої можливий розвиток усіх сторін особистості, врахування її суб'єктивних потреб і об'єктивних умов, пов'язаних 3 матеріальною базою у кадровому потенціалі освіти. Розвиток особистості в гармонії із загальнолюдською культурою залежить від рівня засвоєння базової гуманітарної культури. Ця закономірність зумовлює культурологічний підхід до відбору змісту освіти. У зв'язку з цим самовизначення особи у світовій культурі - стрижнева лінія гуманітаризації змісту освіти» [5, с. 159].

В. Сиволога вважає, що гуманітаризація передбачає передусім залучення молодої людини до гуманітарної культури людства, тобто гуманітаризація розглядається як додатковий і необхідний компонент профресійної освіти [6].

Гуманітаризувати освіту-значить зробитиїїособистісно значущою для кожної конкретної людини, виявити особистісні смисли освіти та навчальних дисциплін, що вивчаються. Стрижнем гуманітаризації освіти є гуманітарне мислення і гуманістична технології педагогічної діяльності [7, с. 189].

Формулюючи принципи гуманітаризації, Р. Євсович вказує на національну спрямованість, залучення до світової культури, критичне осмислення історії, подій і явищ, активну громадянську позицію [8].

Ми згодні з думкою П. Скляр та Т. Уманської, котрі зазначають, що «гуманітаризацію освіти варто розуміти не тільки як поширення та збільшення гуманітарних наук, а як систематичне фрормування людяного ставлення до оточуючих, навколишнього світу та самого себе» [9, с. 97].

Узагальнюючи наведені визначення, під гуманітаризацієюбудеморозумітисистемуорганізаційних, методологічних, психологічнихзаходів, спрямовану на проникнення гуманістичних ідей і гуманітарних знань у природничі знання, зокрема хімічні.

Аналіз стану проблеми показує, що гуманітаризація освіти є стрижневою частиною гуманізації і полягає в глибокій передачі гуманітарних знань, посиленні гуманітарних аспектів природничих наук, у тому числі і хімії, а також розширенні наукового світогляду. Вона спрямована на побудову цілісної картини світу, зокрема світу культури, світу людини, на олюднення знань. Окрім того, гуманітаризація спонукає до розвитку творчих здібностей студента, оволодіння ним різних способів взаємодії з навколишнім світом.

У будь-якому знанні, яке пропонується майбутньому вчителю, належить окреслити акумульований у ньому ціннісний досвід людства. Гуманітарне викладання вузівських дисциплін передбачає: по-перше, глибоке занурення викладача і студента в духовно-культурний контекст інфрормаційних блоків; по-друге, системно організовану оцінну діяльність (монологічну і діалогічну), насамкінець, особистісно-творчу інтерпретацію отриманої навчальної інорормації [10, с. 110].

Гуманітаризація освіти майбутніх учителів хімії має бути зорієнтована на виконання соціального замовлення суспільства, а саме підготовки високоерудованих, конкурентоздатних фахівців, здатних ефективно вирішувати професійні завдання, і водночас на виховання культурної людини, що має необхідний запас природничих знань і здатна передавати ці знання майбутнім поколінням. Окрім того, учительська професія передбачає взаємодію 3 іншими людьми, в ході якої відбувається особистісне взаємозбагачення і розвиток.

Аналіз джерельної бази дослідження дає змогу констатувати, що гуманітаризація освітнього простору підготовки майбутніх учителів хімії має на меті розвиток загальної і профресійної культури, засвоєння гуманітарного потенціалу кожної галузі хімічних знань, їх особистісний розвиток шляхом самореалізації в різних видах професійної, соціальної, творчої діяльності, а отже, і реалізацію професійного самовизначення.

Таким чином, для гуманітаризації освітнього процесу майбутніх учителів хімії необхідно:

- виділити гуманітарний потенціал хімічних дисциплін, який є частиною людської культури;

- відобразити його в змісті освіти, що дасть змогу сорормувати цілісний науковий світогляд майбутніх фрахівців;

- відібрати ефективні методи, форми та засоби навчання, що дадуть змогу сорормувати досвід розумової, пошукової, творчої, трудової діяльності студентів; досвід їх емоційно-ціннісних відносин тощо;

- використання технологій навчання, які сприяють найбільш повному прояву творчих здібностей студентів, їх самостійності;

- особистісно орієнтований підхід в освіті, облік індивідуальних особливостей і схильностей студентів.

Гуманітаризація освіти не має зводитися тільки до підвищення питомої ваги гуманітарних навчальних дисциплін. Вона має охоплювати абсолютно всі галузі наукових знань, що входять до переліку навчальних предметів, котрі вивчаються студентами. 
На нашу думку, можна виділити такі напрями гуманітаризації хімічних дисциплін:

- посилення їх методологічної, світоглядної орієнтації;

- фрормування системи знань про людину як об'єкт і суб'єкт пізнання;

- культурно-історичний (соціально-культурний) підхід;

- культурологічний підхід;

- навчання вирішувати наукові проблеми на кордоні хімічної та гуманітарної сфрер;

- інтеграційний підхід: взаємопроникнення гуманітарних знань і хімії.

Важливим напрямом гуманітаризації хімічних дисциплін, на нашу думку, є посилення їх методологічного, світоглядного спрямування. Зокрема, це можливо через аналіз і оцінку світоглядного змісту та методологічного значення основних понять, теорій, законів хімії, застосування їх в інших галузях науки, техніці тощо. Це дасть можливість студентам отримати сучасне, цілісне наукове уявлення про матерію і фрорми її руху, про речовину як про один з видів матерії, що рухається, про механізм перетворення речовин, про роль хімії в науковотехнічному прогресі.

Ми вважаємо, що ефективним напрямом гуманітаризації освіти $€$ викладання хімічних дисциплін у культурно-історичному (соціально-культурному) контексті. Студенти мусять знати, як проходила трансорормація знань у культурі і науці, як вони зберігалися, розвивалися і застосовуються в сучасному світі. У цьому ракурсі доречним $€$ збагачення хімічних дисциплін знаннями, що розкривають боротьбу наукових ідей, біографрічні відомості про видатних учених, співвідношення наукових відкриттів із сучасними подіями світової історії, видатними досягненнями в літературі, музиці, живописі, залежність науково-технічного прогресу від особистісних якостей людини, її творчих здібностей.

На нашу думку, важливим шляхом гуманітаризації хімічної освіти є культурологічний підхід, який дає можливість пов'язати хімію 3 цінностями матеріальної та духовної культури людства. Дуже важливо, щоб матеріал хімічних дисциплін був наповнений культурологічним змістом. Тобто хімічна інорормація, яку отримують студенти, має сприйматися ними як невід'ємний компонент культурного життя. Студенти мають отримати не тільки суто хімічні знання (факти, теорії, закони тощо), а й відчути особистісно-емоційне ставлення до матеріалу, що викладається.

Серед основних напрямів гуманітаризації хімічної освіти важливе місце посідає інтеграційний підхід: взаємопроникнення гуманітарних знань і хімії. Ми пропонуємо збагатити традиційний зміст хімічних дисциплін у педагогічному закладі вищої освіти завданнями, спрямованими на застосу- вання одержаних знань у ситуаціях, близьких до їхньої майбутньої професійної діяльності. Головне місце в цьому напрямі посідають контекстні та ситуаційні завдання практико-орієнтованого типу, які, з одного боку, мають значний мотиваційний, предметний чи міжпредметний потенціал, а 3 іншого - моделюють актуальні проблемні ситуації в їхній майбутній професійній діяльності.

Одним зі способів гуманітаризації освіти під час підготовки майбутніх вчителів хімії, на нашу думку, є використання наративу як особливої форми представлення хімічних знань.

Поняття наративу нині перебуває в центрі уваги не тільки гуманітарних наук: фрілософії, наратології, лінгвістики, психології, соціології тощо, а й за їх межами, зокрема і в природничих науках.

Слово «наратив» походить від латинського narrare - мовний акт, розповідь, водночас воно $€$ спорідненим із також латинським словом gnarus знати. Таким чином, уже в перекладі цього слова вбачається ідея - перехід «знання» в «розповідь».

Особливу увагу, враховуючи тему нашого дослідження, привертає до себе думка А. Карабаєвої, що наратив є універсальною характеристикою культури, а розповідь - це не просто засіб передачі інформації або елементарний інститут людської комунікації, це спосіб одержання якісної (некількісної) інфрормації, пов'язаної із нововведеннями [11].

У контексті нашого дослідження зауважимо, що наратив $€$ одним 3 ефективних способів особистісно орієнтованого підходу, який сприяє більш повному розкриттю індивідуальності студента, прояву уваги й інтересу до його особи з боку викладача і одногрупників, фрормує пізнання навколишньої дійсності, самопізнання, самовираження і самовизначення, в тому числі і професійне.

Варто відзначити, що наратив, як спосіб і форма передачі наукових знань у процесі навчання, можна вважати дидактичною категорією - навчальним наративом. Навчальний наратив - це форма передачі наукових знань у формі завершеного оповідання, яке має такі характеристики: послідовність і завершеність дії; хронологічний або підпорядкований єдиній логіці порядок розташування подій; власна оцінка оповідачем значення подій [12].

У змісті курсу хімії, крім традиційних питань, що стосуються хімічних елементів, речовин і реакцій, належна увага приділяється висвітленню наукового пізнання в хімії, ролі теоретичних й експериментальних досліджень, екологічної складової частини хімічних знань, впливу хімічних чинників на здоров'я людини. Усі ці питання можуть служити фрабулою для створення наративів. Уже на основі фрабули розвивається сюжет, викладаються події у власній інтерпретації [12].

Виконуючи фрункцію специфрічного способу викладу знань, наратив не просто реєструє події, 
він констатує й інтерпретує їх як значущі частини осмисленого цілого, причому цілим може бути ситуація або суспільство, проєкт або подія тощо. Наратив може дати пояснення певного поняття, відобразити зв'язок між ними тощо. Для викладання хімії це суттєво [12].

Навчальний наратив може набувати різних форм і представлятися як викладачем, так і студентами. Створення навчальних наративів студентами є особливо цінним, оскільки шукаючи і відбираючи наукову інфрормацію, вони вчаться ії критично оцінювати, висловлювати своє ставлення до такого питання, інтерпретувати тощо. Студенти, які можуть передавати інорормацію, вкладаючи в неї не тільки хімічні знання, а й своє ставлення до них, зможуть повною мірою зацікавити, змотивувати до вивчення хімії своїх майбутніх учнів.

Гуманітаризація хімічної освіти під час підготовки майбутніх учителів потребує використання ефективних методів, фрорм і засобів, інноваційних технологій навчання, які сприяли б формуванню гуманітарного стилю мислення, творчих здібностей, необхідних для сприйняття цілісності й гармонії світу.

Підсумовуючи все сказане вище, можемо зробити висновок, що гуманітаризація освітнього процесу у педагогічних закладах вищої освіти під час підготовки майбутніх учителів хімії передбачає зміну змісту, структури, методів і засобів навчання таким чином, щоб вони в повному обсязі відповідали рівню світової культури загалом. Мається на увазі залучення історичного досвіду, багатих духовних і загальнокультурних традицій, досягнень світової культури, науки і техніки тощо.

Висновки. У процесі дослідження ми дійшли висновку, що гуманітаризація освітнього процесу під час підготовки учителів хімії в педагогічних закладах вищої освіти є необхідною складовою частиною освітнього процесу і важливою умовою формування готовності майбутніх учителів-хіміків до реалізації професійного самовизначення.

На нашу думку, такий підхід дасть змогу підготувати висококваліфрікованого і всебічно розвиненого учителя хімії, котрий зможе 3 легкістю орієнтуватися як у хімії, так і в змісті інших фрундаментальних дисциплін, здатного до саморозвитку і самоосвіти, фрахівця 3 високою мотиваційною готовністю до професійно-творчої діяльності.

Проведене дослідження не охоплює всіх аспектів проблеми. Перспективи подальших розвідок вбачаємо в дослідженні традиційних та інноваційних фрорм, методів і засобів гуманітаризації освітнього процесу та їхнього впливу на інтенсивність формування готовності до професійного самовизначення майбутніх учителів хімії.

\section{БІБЛІОГРАФІЧНИЙ СПИСОК:}

1. Поляков В.А., Чистякова С.Н. Профрессиональное самоопределение молодёжи. Москва : Педагогика. 1993. № 5. С. 33-37.

2. Кипурова С.Н., Малий Д.В. Сущность профессионального самоопределения студента вуза. Известия ТулГУ. Гуманитарные науки. 2014. № 4-2. C. 108-117.

3. Форостовська Т.О. Застосування інноваційних методів навчання як умова фрормування готовності до професійного самовизначення майбутніх учителів. Сучасні інформаційні технології та інноваційні методики навчання у підготовці фрахівців: методологія, теорія, досвід, проблеми. 2018. Вип. 51. С. 420-424.

4. Енциклопедія освіти / Акад. пед. наук України; головний ред. В.Г. Кремень. Київ : Юрінком Інтер, 2008. $1040 \mathrm{c}$.

5. Чермит К.Д., Левченко В.Г. Высшее образование: реалии и перспективы. Майкоп : Редакционноиздательский отдел Адыгейского государственного университета, 2001. 237 с.

6. Сиволога В.Ф. Гуманізація та гуманітаризація вищої освіти. Дослідження політичної взаємодії в умовах транссрормації суспільства : зб. наук. праць. Одеса: ОНУ, 2013. С. 266-286.

7. Викулина М.А. Гуманитарная сущность профессиональной подготовки современного учителя. Известия высших учебных заведений. Поволжский регион. Гуманитарные науки. 2014. № 4. C. $186-196$.

8. Євсович Р.В. Гуманізація та гуманітаризація вищої освіти в Україні: історичний аспект. Духовність особистості: методологія, теорія і практика. 2012. № 5 (52). C. 79-87.

9. Скляр П.П., Уманська Т.О. «Гуманізація» та «гуманітаризація»: поняття, співвідношення та шляхи впровадження в освіту. Вісник Національного технічного університету України «Київський політехнічний інститут». Філософрія. Психологія. Педагогіка. 2007. № 1. С. 92-101.

10. Тарасенко Г.С. Гуманітаризація вищої педагогічної освіти в контексті фрілософрсько-педагогічного аналізу. Педагогічна освіта: теорія і практика. Кам'янець-Подільський нац. ун-т імені І. Огієнка. 2015. № 18. С. 105-110.

11. Карабаева А.Г. Нарратив в науке и образовании. Серия "Symposium", Инновации и образование. Выпуск 29. Сб. материалов конореренции. Санкт-Петербург : Санкт-Петербургское фрилософское общество, 2003. С. 89-96.

12. Форостовская Т.А. Нарративная форма представления химических знаний. Austrian Journal of Humanities and Social Sciences. 2014. № 7-8. Vienna. P. 141-143. 